\title{
Nickel(II) complexes of novel thiosemicarbazone compounds: Synthesis, characterization, molecular modeling and in vitro antimicrobial activity
}

\author{
Mutlaq Shedeed Aljahdali \\ Department of Chemistry, Faculty of Science, King Abdulaziz University, Jeddah 21589, The Kingdom of Saudi Arabia \\ *Corresponding author at: Department of Chemistry, Faculty of Science, King Abdulaziz University, Jeddah 21589, The Kingdom of Saudi Arabia. \\ Tel.: +9.66.503617791; fax: +9.66. 26952293. E-mail address: mutlaqaljahdali@yahoo.com (M.S. Aljahdali).
}

\section{ARTICLE INFORMATION}

Received: 30 May 2013

Received in revised form: 03 July 2013

Accepted: 03 July 2013

Online: 31 December 2013

\section{KEYWORDS}

Spectra

Antifungal

Hydrazine

Antibacterial

Thiosemicarbazone

Molecular modeling

\begin{abstract}
A series of novel thiosemicarbazone compounds, HL1, 2-(1-(2-phenyl-hydrazono)-propan-2ylidene)hydrazine-carbothioamide (TPHP), $\mathrm{HL}^{2}, \quad N$-methyl-2-(1-(2-phenyl-hydrazono)propan-2-ylidene)hydrazinecarbothioamide (MTPHP) and, $\mathrm{HL}^{3}, \mathrm{~N}$-phenyl-2-(1-(2-phenylhydrazono)-propan-2-ylidene)hydrazinecarbothioamide (PTPHP) and their Ni(II) complexes have been synthesized and characterized using elemental analysis, magnetic susceptibility, molar conductance and spectral measurements. IR spectra indicate that the free ligands exist in the thione form rather than thiol form in the solid state. In all the studied complexes, all ligands behave as a tridenate anion with coordination involving the two azomethine nitrogens and the thiolate sulfur after deprotonation. The magnetic and spectral data indicates a square planar geometry for Ni(II) complexes. The structures of the free thiosemicarbazone ligands and their Ni(II) complexes have been modelled using parameterized PM3 semiempirical method. The free ligands and their Ni(II) chelates have been screened for their antimicrobial activities.
\end{abstract}

\section{Introduction}

In recent years, the number of life-threatening infection diseases caused by multi-drug resistant Gram-positive and Gram-negative bacteria has reached an alarming level in many countries around the world [1]. More than 50 million people worldwide are infected and up to 110,000 of these die every year. Antibiotics provide the main basis for the therapy of microbial (bacterial and fungal) infections. However, overuse of antibiotics has become the major factor for the emergence and dissemination of multi-drug resistant strains of several groups of microorganisms [2]. Furthermore, the drugs available are either too expensive or have many undesirable side effects [3]. Thus, in light of the evidence of rapid global spread of resistant clinical isolates, the need to find new antimicrobial agents is of paramount importance. Considerable attention has been focused on thiosemicarbazone and hydrazone compounds due to their wide biological activities [4,5]. Thiosemicarbazones have been extensively studied because they have a wide range of actual or potential medical applications [6] which include notably antiparasital [7], antibacterial [8] antitumor activities [9], antiviral [10], fungicidal [11] and antineoplastic [12]. In general, thiosemicarbazones are obtained by condensation of the corresponding thiosemicarbazide with aldehydes or ketones. Thiosemicarbazones (TSCNs) exist in the tautomeric thione (A) and thiol (B) forms (Scheme 1). Hydrazones were important class of ligands, such ligands have interesting ligation properties due to presence of several coordination sites [13]. Hydrazone and its derivatives possessing antiinflammatory, analgesic [14], antibacterial [15] and antitumor [16] activities are also reported in the literature. The inhibitory action of these compounds is attributed to their chelating properties to different metal ions that can be found in biological systems which microorganisms need in their metabolism [17]. It is possible to obtain complexes that are more efficient drugs than the corresponding free ligands $[18,19]$. Nickel complexes with thiosemicarbazone were amongst the first complexes tested for their anticancer activity [20]. The antimicrobial and antitumor activity of $\mathrm{Ni}(\mathrm{II})$ complexes have been noticed $[15,21,22]$ and explored in the last few decades [23]. With this in mind, it seems therefore of considerable interest to synthesize and characterize $\mathrm{Ni}(\mathrm{II})$ complexes with the novel ligands containing both the thiosemicarbazone and hydrazo moieties (Scheme 2). Additionally, our objective is also to study the antibacterial and antifungal activities of the synthesized compounds.

\section{Experimental}

\subsection{Materials and reagents}

All reagents and solvents were reagent grade. $\mathrm{NiCl}_{2} .6 \mathrm{H}_{2} \mathrm{O}$, $\mathrm{HCl}$ and $\mathrm{KOH}$ were provided by BDH (British Drug House). Aniline, ethyl acetoacetate and sodium nitrite were obtained from Sigma. Thiosemicarbazide, 4-( $N$-methyl)-thiosemicarbazide and 4-( $\mathrm{N}$-phenyl)-thiosemicarbazide were purchased from Merck. All reagents are used without further purification.

\subsection{Synthesis}

\subsubsection{Synthesis of 1-(phenyl-hydrazono)-propan-2-one} (PHP)

1-(Phenyl-hydrazono)-propan-2-one is prepared as reported in the literature $[15,24]$ as follows: in a $4 \mathrm{~L}$ beaker equipped with a mechanical stirrer, $65 \mathrm{~g}(64 \mathrm{~mL}, 0.5 \mathrm{moles})$ of ethyl acetoacetate was added to $35 \mathrm{~g}(0.53$ moles $)$ of $85 \%$ potassium hydroxide in $1120 \mathrm{~mL}$ of water. 


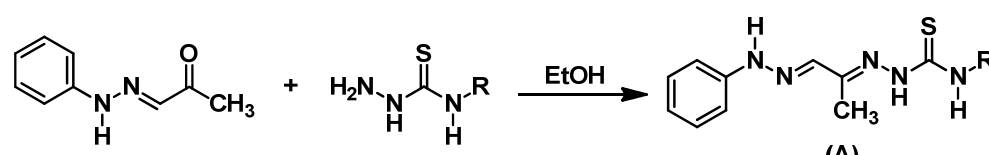

(A)

$\mathrm{R}=\mathrm{H}$ (TPHP), $\mathrm{CH}_{3}$ (MTPHP), Ph (PTPHP)<smiles>[R]N/C(S)=N/N=C(C)/C=N/Nc1ccccc1</smiles>

(B)

Scheme 1

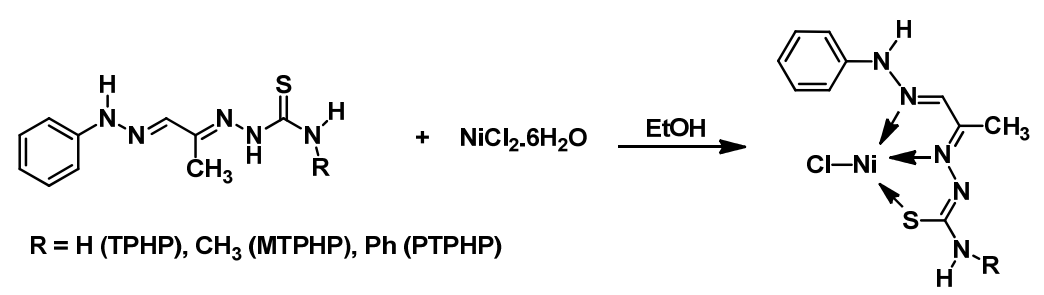

Scheme 2

The mixture is allowed to stand at room temperature for 24 h. Forty-seven grams ( $48 \mathrm{~mL}, 0.5$ moles) of aniline is dissolved in $200 \mathrm{~mL}$ of aqueous $\mathrm{HCl}$ (prepared from equal volumes of concentrated acid and water) in a $2 \mathrm{~L}$ beaker. The beaker is equipped with a mechanical stirrer and immersed in an ice-salt bath. After the solution has cooled to $0-5{ }^{\circ} \mathrm{C}, 36 \mathrm{~g}$. ( 0.52 mole $)$ of sodium nitrite dissolved in $1 \mathrm{~L}$ of water is added slowly, with stirring, from a separatory funnel. The tip of the stem of the seperatory funnel dipped well below the surface of the liquid. The rate of addition is adjusted to maintain the temperature between 0 and $5{ }^{\circ} \mathrm{C}$. A drop of the reaction mixture is tested from time to time with starch-iodide paper until nitrous acid persists in the solution during a 5 min interval. The solution of potassium acetoacetate is cooled to $0{ }^{\circ} \mathrm{C}$, and $45 \mathrm{~mL}$ of concentrated $\mathrm{HCl}$ in $150 \mathrm{~mL}$ of ice water is added slowly with stirring. The diazonium salt solution is then added over a period of $20 \mathrm{~min}$, and the mixture is made basic by the addition of $82 \mathrm{~g}$ of sodium acetate dissolved in $300 \mathrm{~mL}$ of water. The temperature of the reaction mixture is raised slowly to $50{ }^{\circ} \mathrm{C}$ and maintained at this temperature for $2 \mathrm{~h}$; the separated solid is collected on a filter and dried. The yield of crude product is $77 \mathrm{~g}(95 \%)$. Purification can be effected by recrystallization from $200 \mathrm{~mL}$ of toluene. The purified product weighs $66 \mathrm{~g}$ (82\%); M.p.: $148-150^{\circ} \mathrm{C}$.

\subsubsection{Synthesis of thiosemicarbazone compounds}

The general route of synthesis (Scheme 1) is shown in the following. Equimolar amounts of (PHP) $(0.1620 \mathrm{~g}, 1 \mathrm{mmol})$ in $25 \mathrm{~mL}$ ethanol with an ethanolic solution $(25 \mathrm{~mL})$ of thiosemicarbazide $(0.0911 \mathrm{~g}, 1 \mathrm{mmol})$, methyl $(0.1051 \mathrm{~g}$, 1 mmol) and phenyl ( $0.1672 \mathrm{~g}, 1 \mathrm{mmol})$ thiosemicarbazides. The reaction mixture was then refluxed on a hot plate for $4-5 \mathrm{~h}$. The obtained precipitates were separated out, filtered off, washed with diethyl ether and dried overnight under silica gel. The proposed chemical structures of the prepared thiosemicarbazone compounds are in a good agreement with the stoichiometries concluded from their analytical data and confirmed by the IR spectral data.

\subsubsection{Synthesis of complexes}

$\mathrm{Ni}(\mathrm{II})$ complexes were prepared as shown in Scheme 2. The appropriate quantity of the thiosemicarbazone ligand ( $1 \mathrm{mmol}$ ) was dissolved in absolute EtOH $(30 \mathrm{~mL})$. To this solution an ethanolic solution of $(1 \mathrm{mmol})$ of $\mathrm{NiCl}_{2} \cdot 6 \mathrm{H}_{2} \mathrm{O}$ was added dropwise [1:1 molar ratio, $\mathrm{M}: \mathrm{L}]$. The reaction mixtures were refluxed on a water bath for $5 \mathrm{~h}$ and allowed to cool to room temperature overnight. The precipitated complexes were then filtered off, washed with petroleum ether and dried overnight in a vacuum desiccator.

\subsection{Molecular modeling}

An attempt to gain a better insight on the molecular structure of these synthesized thiosemicarbazone compounds and their $\mathrm{Ni}(\mathrm{II})$-complexes, geometric optimization and conformation analysis has performed using semiempirical parameterized PM3 method as implemented in HyperChem 7.5 [25]. Convergence criteria were set to $0.01 \mathrm{kcal} / \mathrm{mol} . \AA$ for PM3 calculations.

\subsection{Biological activity}

\subsubsection{Antibacterial and antifungal activities}

Antimicrobial activity of the tested samples was determined using a modified Kirby-Bauer disc diffusion method [26]. Briefly, $100 \mu \mathrm{L}$ of the test bacteria/fungi were grown in $10 \mathrm{~mL}$ of fresh media until they reached a count of approximately $10^{8}$ cells $/ \mathrm{mL}$ or $10^{5}$ cells $/ \mathrm{mL}$ for fungi [27]. 100 $\mu \mathrm{L}$ of microbial suspension was spread onto agar plates corresponding to the broth in which they were maintained. Isolated colonies of each organism that might be playing a pathogenic role should be selected from primary agar plates and tested for susceptibility by disc diffusion method of the National Committee for Clinical Laboratory Standards (NCCLS) [28]. Of the many media available, NCCLS recommends Mueller-Hinton agar due to: it results in good batch-to-batch reproducibility. 
Table 1. Analytical and physical data of Ni(II)-complexes.

\begin{tabular}{|c|c|c|c|c|c|c|c|}
\hline \multirow[t]{2}{*}{ Compound } & \multirow[t]{2}{*}{ Yield, \% } & \multirow[t]{2}{*}{ Formula } & \multirow[t]{2}{*}{ M.wt, g } & \multicolumn{4}{|c|}{ \% Found (Calcd.) } \\
\hline & & & & C & $\mathrm{H}$ & $\mathbf{N}$ & $\mathbf{S}$ \\
\hline TPHP & 72 & $\mathrm{C}_{10} \mathrm{H}_{13} \mathrm{~N}_{5} \mathrm{~S}$ & & $51.02(50.98)$ & $5.53(5.40)$ & $29.78(29.70)$ & $13.62(13.60)$ \\
\hline MTPHP & 67 & $\mathrm{C}_{11} \mathrm{H}_{15} \mathrm{~N}_{5} \mathrm{~S}$ & & $53.01(53.01)$ & $6.02(5.96)$ & $28.11(27.80)$ & $12.85(12.80)$ \\
\hline PTPHP & 63 & $\mathrm{C}_{16} \mathrm{H}_{17} \mathrm{~N}_{5} \mathrm{~S}$ & & $61.71(61.60)$ & $5.46(5.40)$ & $22.50(22.49)$ & $10.29(10.22)$ \\
\hline$[\mathrm{Ni}(\mathrm{TPHP}) \mathrm{Cl}] \cdot \mathrm{H}_{2} \mathrm{O}(1)$ & 75 & $\mathrm{C}_{10} \mathrm{H}_{14} \mathrm{~N}_{5} \mathrm{SONiCl}$ & 346.46 & 34.59 (34.67) & $4.05(4.07)$ & $20.18(20.21)$ & $9.17(9.23)$ \\
\hline [Ni(MTPHP)Cl] (2) & 73 & $\mathrm{C}_{11} \mathrm{H}_{14} \mathrm{~N}_{5} \mathrm{SNiCl}$ & 342.47 & 38.44 (38.58) & $4.08(4.12)$ & $20.41(20.45)$ & $9.31(9.36)$ \\
\hline [Ni(PTPHP)Cl] (3) & 70 & $\mathrm{C}_{16} \mathrm{H}_{16} \mathrm{~N}_{5} \mathrm{SNiCl}$ & 404.54 & $47.38(47.50)$ & $3.98(3.99)$ & $17.28(17.31)$ & $7.90(7.93)$ \\
\hline
\end{tabular}

Disc diffusion method for filamentous fungi tested by using approved standard method (M38-A) developed by the NCCLS [29] for evaluating the susceptibilities of filamentous fungi to antifungal agents. Disc diffusion method for yeasts developed by using approved standard method (M44-P) by the NCCLS [30]. Plates inoculated with filamentous fungi as as (Aspergillus flavus RCMB 02568, Penicillium italicum RCMB 03924, Candida albicans RCMB 05031, Geotricum candidum RCMB 05097) at 30 ${ }^{\circ} \mathrm{C}$ for 24-48 hours; Gram (+) bacteria as (Bacillus subtillis RCMB 010067, Staphylococcus aureus RCMB 010028); Gram (-) bacteria as (Pseudomonas aeuroginosa RCMB 010043, Escherichia coli RCMB 010052), they were incubated at 35-37 ${ }^{\circ} \mathrm{C}$ for 24-48 hours and then the diameters of inhibition zones were measured in millimeters [31]. Standard discs of Gentamicin (Antibacterial agents) and Amphotericin B (Antifungal agent) served as positive controls for antimicrobial activity but filter discs impregnated with $10 \mu \mathrm{L}$ of solvent (DMSO) were used as a negative control. The agar used is Mueller-Hinton agar that is rigorously tested for composition and $\mathrm{pH}$. Further the depth of the agar in the plate is a factor to be considered in the disc diffusion method. This method is well documented and standard zones of inhibition have been determined for susceptible and resistant values. Blank paper disks (Schleicher and Schuell, Spain) with a diameter of $8.0 \mathrm{~mm}$ were impregnated with $10 \mu \mathrm{L}$ of tested concentration of the stock solutions. When a filter paper disc impregnated with a tested chemical is placed on agar, the chemical will diffuse from the disc into the agar. This diffusion will place the chemical in the agar only around the disc. The solubility of the chemical and its molecular size will determine the size of the area of chemical infiltration around the disc. If an organism is placed on the agar, it will not grow in the area around the disc if it is susceptible to the chemical. This area of no growth around the disc is known as a "Zone of inhibition" or "Clear Zone". For the disc diffusion, the zone diameters were measured with slipping calipers of the (NCCLS) [30]. Agar-based methods such as E-test and disk diffusion can be good alternatives because they are simpler and faster the broth-based methods [32]. The antibacterial results of the compounds were compared with the standard and \% activity index for the compounds was calculated by using the formula as given below:

$\%$ Activity index $=\frac{\text { Zone of inhibition by test compound (diameter) }}{\text { Zone of inhibition by standard (diameter) }} \times 100$

\subsubsection{Minimum inhibitory concentration (MIC)}

Compounds showing promising antibacterial/antifungal activity were selected for minimum inhibitory concentration (MIC) studies. The MIC is the lowest concentration of the test compound, which inhibits the visible growth of microorganisms after incubation, and the minimum inhibitory concentration $\mathrm{s}$ are important in diagnostic laboratories to confirm the resistance of microorganisms to antimicrobial agents. The synthesized compounds were screened against bacterial and fungal strains using agar plate method, two fold serial dilutions of each test compound was used. The culture of each organism was diluted by sterile distilled water to $10^{5}-10^{6}$ $\mathrm{CFU} \backslash \mathrm{mL}$. The cultures were incubated at $37{ }^{\circ} \mathrm{C}$ for 24 hour (bacteria) and at $28^{\circ} \mathrm{C}$ for 3 to 4 days (fungi). DMSO was used as negative control.

\subsection{Instrumentation}

The microchemical analysis of the separated solid compounds was carried out at the Department of Chemistry, Faculty of Science, King Abdul-Aziz University, Jeddah, 21589, KSA. The analyses were performed twice to check the accuracy of the analyses data. Infrared spectra were recorded on a 8001PC FT-IR Shimadzu spectrophotometer using KBr pellets. The solid reflectance spectra were measured on a Schimadzu 3101 PC spectrophotometer. The room temperature magnetic susceptibility measurements for the complexes were determined by the Gouy balance using $\mathrm{Hg}\left[\mathrm{Co}(\mathrm{SCN})_{4}\right]$ as a calibrant.

\section{Results and discussion}

The isolated thiosemicarbazone compounds are formed by the interaction of PHP with thiosemicarbazide and its derivatives in a molar ratio 1:1 under reflux conditions (Scheme 1). The formulation of these compounds based on the elemental analysis (Table 1), IR, and electronic spectra. The solid compounds are air stable. These compounds are colored, insoluble in $\mathrm{H}_{2} \mathrm{O}$ and other common organic solvents like methanol and ethanol but soluble in dimethylformamide (DMF) and dimethylsulphoxide (DMSO). Attempts to obtain single crystal suitable for X-ray determination were unsuccessful, thus molecular modeling for these thiosemicarbazone compounds and their Ni(II)-complexes were investigated. The interaction of thiosemicarbazone ligands with nickel (II) chloride (Scheme 2) in EtOH in a molar ratio 1:1 under reflux conditions gave the products formulated as [ $\mathrm{NiLCl}] \cdot \mathrm{nH}_{2} \mathrm{O}$ where $\mathrm{L}$ is the deprotonated ligand.

\subsection{Infrared spectra}

The tentative assignments of the significant IR spectral bands of the free thiosemicarbazone compounds and their nickel(II) complexes revealing the following features (Table 2). Thiosemicarbazone compounds, in principle exhibit thione $\leftrightarrow$ thiol tautomerism due to the presence of a thiol amide $-\mathrm{NH}-\mathrm{C}=\mathrm{S}$ linkage [33]. The absence of $v(\mathrm{~S}-\mathrm{H})$ absorption band in the region $2500-2600 \mathrm{~cm}^{-1}$ with a band around $750 \mathrm{~cm}^{-1}$ due to $v(\mathrm{C}=\mathrm{S})$ suggesting absence of any thiol tautomer and all thiosemicarbazone compounds remain in the thione form in the solid state. All of the thiomamide bands are shifted to some degree but the most significant change is that observed in the thioamide IV band, which contain the largest proportion of $v(\mathrm{CS})$ activity, i.e. the $\mathrm{C}=\mathrm{S}$ on coordination gains $\mathrm{C}$-S character. The negative shift of the $v(\mathrm{C}=\mathrm{S})$ band in the complexes confirm the coordination via the thiolate sulfur $[34,35]$. The spectra of the free (TPHP) show two bands at 3265 and $3384 \mathrm{~cm}^{-1}$, due to $v_{\text {sym }}$ and $v_{\text {asym }}$ of the $\mathrm{NH}_{2}$ group. These absorptions remain unaltered in the metal complexes confirming the noninvolvement of this terminal $\mathrm{NH}_{2}$ group upon coordination. In the ligands spectra, the strong band observed in the range $1595-1600 \mathrm{~cm}^{-1}$ is assigned to $v(\mathrm{C}=\mathrm{N})$ stretching vibration [36]. 
Table 2. Tentative assignment of the important infrared bands of the synthesized complexes.

\begin{tabular}{|c|c|c|c|c|c|c|c|c|c|c|c|c|c|}
\hline \multirow[t]{2}{*}{ Compound } & \multirow[t]{2}{*}{$v_{\mathrm{OH}}$} & \multirow[t]{2}{*}{$v_{\mathrm{NH} 2}$} & \multicolumn{4}{|c|}{ Thioamide band } & \multirow{2}{*}{$v_{\mathrm{N} 2 \mathrm{H}}$} & \multirow[t]{2}{*}{$\mathbf{v}_{\mathrm{N} 5 \mathrm{H}}$} & \multirow[t]{2}{*}{$\mathbf{V}_{\mathrm{C}=\mathrm{N}}$} & \multirow[t]{2}{*}{$\mathbf{v}_{\mathrm{N}-\mathrm{N}}$} & \multirow[t]{2}{*}{$\mathbf{v}_{\mathrm{Ni}-\mathrm{N}}$} & \multirow[t]{2}{*}{$\mathbf{v}_{\mathrm{Ni}-\mathrm{S}}$} & \multirow[t]{2}{*}{$\mathbf{v}_{\mathrm{Ni}-\mathrm{C}}$} \\
\hline & & & I & II & III & IV & & & & & & & \\
\hline$\overline{\mathrm{TPHP}}$ & - & 3265,3384 & 1500 & 1247 & - & 750 & 3151 & - & 1595 & 1068 & - & - & - \\
\hline MTPHP & - & - & 1492 & 1255 & 3357 & 752 & 3213 & 3357 & 1600 & 1070 & - & - & - \\
\hline РТPHP & - & - & 1515 & 1257 & 3346 & 750 & 3251 & 3346 & 1600 & 1070 & - & - & - \\
\hline$[\mathrm{Ni}(\mathrm{TPHP}) \mathrm{Cl}] \cdot \mathrm{H}_{2} \mathrm{O}$ & 3510 & 3245,3372 & 1498 & 1245 & & 710 & & & 1565 & 1076 & 450 & 360 & 280 \\
\hline [Ni(MTPHP)Cl] & - & - & 1492 & 1252 & 3330 & 711 & - & 3330 & 1562 & 1079 & 445 & 360 & 285 \\
\hline [Ni(PTPHP)Cl] & - & - & 1515 & 1254 & 3328 & 718 & - & 3328 & 1560 & 1079 & 448 & 352 & 288 \\
\hline
\end{tabular}

Table 3. Molar conductance and electronic spectral data $\left(\mathrm{cm}^{-1}\right)$ of the complexes.

\begin{tabular}{|c|c|c|c|c|c|}
\hline Compounds & $\Lambda_{\mathrm{M}}{ }^{\mathrm{a}}$ & $n \rightarrow \pi^{*}$ & $\pi \rightarrow \pi^{*}$ & $\mathbf{L} \rightarrow \mathbf{M}$ & $d-d$ \\
\hline TPHP & - & 27472 & 32787 & - & - \\
\hline МТPHP & - & 27548 & 32894 & - & - \\
\hline PTPHP & - & 26809 & 33003 & - & - \\
\hline$[\mathrm{Ni}(\mathrm{TPHP}) \mathrm{Cl}] \cdot \mathrm{H}_{2} \mathrm{O}$ & 6.76 & 28301 & 33430 & $\begin{array}{l}25321 \\
30870\end{array}$ & 18815 \\
\hline [Ni(MTPHP)Cl] & 5.23 & 28108 & 334001 & $\begin{array}{l}25603 \\
30992\end{array}$ & 19235 \\
\hline [Ni(PTPHP)Cl] & 4.01 & 27309 & 34540 & $\begin{array}{l}25445 \\
31108 \\
\end{array}$ & 19720 \\
\hline
\end{tabular}

a Molar conductance measured for $10^{-3} \mathrm{M}$ DMSO solution, $\Omega^{-1} \mathrm{~cm}^{2} \mathrm{~mol}^{-1}$.

Table 4. Antibacterial activity of thiosemicarbazone compounds.

\begin{tabular}{|c|c|c|c|c|}
\hline \multirow[t]{2}{*}{ Compounds } & \multicolumn{4}{|c|}{ Diameter of inhibition zone (in $\mathrm{mm}$ ) a } \\
\hline & $\begin{array}{l}\text { Pseudomonas aeuroginosa (Gr-) } \\
\text { (RCMB 010043) }\end{array}$ & $\begin{array}{l}\text { Escherichia Coli (Gr-) } \\
\text { (RCMB 010052) }\end{array}$ & $\begin{array}{l}\text { Bacillus subtillis (Gr+) } \\
\text { (RCMB 010067) }\end{array}$ & $\begin{array}{l}\text { Staphylococcus aureus }(\mathrm{Gr}+) \\
\text { (RCMB 010028) }\end{array}$ \\
\hline$\overline{\mathrm{TPHP}}$ & NA & $14.0 \pm 0.64$ & $19.4 \pm 0.64$ & $18.1 \pm 0.35$ \\
\hline MTPHP & NA & $13.4 \pm 0.44$ & $18.2 \pm 0.32$ & $16.7 \pm 0.34$ \\
\hline РТРНP & NA & $13.6 \pm 0.39$ & $18.7 \pm 0.67$ & $17.2 \pm 0.55$ \\
\hline$[\mathrm{Ni}(\mathrm{TPHP}) \mathrm{Cl}] \cdot \mathrm{H}_{2} \mathrm{O}$ & NA & $17.3 \pm 0.49$ & $19.3 \pm 0.24$ & $25.2 \pm 0.45$ \\
\hline [Ni(MTPHP)Cl] & NA & $16.1 \pm 0.34$ & $18.2 \pm 0.25$ & $23.7 \pm 0.49$ \\
\hline [Ni(PTPHP)Cl] & NA & $15.5 \pm 0.25$ & $17.1 \pm 0.12$ & $22.5 \pm 0.24$ \\
\hline Gentamicin & $17.3 \pm 0.15$ & $22.3 \pm 0.18$ & $27.4 \pm 0.18$ & $32.4 \pm 0.10$ \\
\hline
\end{tabular}

a Mean zone of inhibition in $\mathrm{mm} \pm$ standard deviation beyond well diameter $(6 \mathrm{~mm})$ produced on a range of environmental and clinically pathogenic microorganisms using $(1 \mathrm{mg} / \mathrm{mL})$ concentration of tested samples.

In the spectra of complexes, this band was not observed at the same frequencies and the same intensities. They shifted after coordination to lower energies by ca. $33-40 \mathrm{~cm}^{-1}$, indicating coordination via azomethine nitrogen [37]. The $v(\mathrm{~N}-$ $\mathrm{N})$ of the thiosemicarbazone ligands is found at (1068-1070) $\mathrm{cm}^{-1}$. The increase in frequency of this band in the spectra of complexes is an evidence for the enethiolization of the ligands and the coordination via the azomethine nitrogen. The possibility of $\alpha$-nitrogen $\left(\mathrm{N}^{2} \mathrm{H}\right)$ coordination is ruled out because of considerable strain [38]. The bands observed at $3540-3545 \mathrm{~cm}^{-1}$ are due to $v(\mathrm{O}-\mathrm{H})$. As it is known $[34,39,40]$, coordinated water should exhibit frequencies at 825,575 and $500 \mathrm{~cm}^{-1}$. The absence of spectral bands in these regions in the spectra of complexes indicates that the water molecules in these complexes are not coordinated but are present as lattice water. The coordination positions of the thiosemicarbazones in the $\mathrm{Ni}(\mathrm{II})$ complexes are confirmed by assigning the strong bands observed in the far IR spectra of the complexes. The bands observed at (445-450) and (352-360) $\mathrm{cm}^{-1}$ are assigned to $v(\mathrm{Ni}-\mathrm{N})$ [41] and $v(\mathrm{Ni}-\mathrm{S})$ as suggested by Lever [42] respectively. In the literature, the bands appearing between 160 and $300 \mathrm{~cm}^{-1}$ are allotted to the vibration of the M-X bonds where $\mathrm{M}=$ metal and $\mathrm{X}=\mathrm{Cl}$ or $\mathrm{Br}[37,43]$. In our case the $v(\mathrm{Ni}-$ Cl) frequencies appearing between $280-288 \mathrm{~cm}^{-1}$ are in good agreement with the reported values in the literature. Based on the above spectral evidences, it is confirmed that the thiosemicarbazone ligands lost the $\mathrm{N}^{2}$ proton and coordinated to the $\mathrm{Ni}(\mathrm{II})$ ion as mononegative tridentate anion, coordinating via the two azomethine nitrogen atoms and the thiolate sulfur atom after deprotonation.

\subsection{Conductivity measurements}

Conductivity measurements in non-aqueous solutions have frequently been used in structural studies of metal chelates within the limits of their solubility. These measurements were provided a method for testing the degree of ionization of the complexes, the molar ions that a complex liberates in solution, the higher will be its molar conductivity and vice versa. The non-ionized complexes have negligible value of molar conductance. It is clear from the conductivity data (Table 3) that the complexes present seem to be nonelectrolytes (4.01$6.76 \Omega^{-1} . \mathrm{cm}^{2} . \mathrm{mol}^{-1}$ ). Also the molar conductance values indicate that the anions were existed inside the coordination sphere which was also confirmed from the chemical analysis and also $\mathrm{Cl}-$ ion is not precipitated by addition of $\mathrm{AgNO}_{3}$ solution.

\subsection{Electronic spectra}

The probable assignments for the bands in the region 26809-27548 and 33003-32787 $\mathrm{cm}^{-1}$ are due to the $\mathrm{n} \rightarrow \pi^{*}$ and $\pi \rightarrow \pi^{*}$ transitions of thiosemicarbazone compounds, respectively. Always $\mathrm{n} \rightarrow \pi^{*}$ transitions occurs at a lower energy than $\pi \rightarrow \pi^{*}$ transitions [44]. In the spectra of $\mathrm{Ni}(\mathrm{II})$ complexes the bands observed in the region 25321-25603 $\mathrm{cm}^{-1}$ are assigned to $\mathrm{S} \rightarrow \mathrm{Ni}$ charge-transfer band [45]. The bands in the range 30870-31108 $\mathrm{cm}^{-1}$ observed in the spectra of all $\mathrm{Ni}(\mathrm{II})$ complexes are assigned as $\mathrm{Cl} \rightarrow \mathrm{Ni}$ charge-transfer transitions [46]. The shift of the $\pi \rightarrow \pi^{*}$ bands to the longer wavelength region is the result of the $\mathrm{C}=\mathrm{S}$ bond being weakened and conjugation system being enhanced after the formation of the complex [47]. The electronic spectra of the nickel(II) complexes (Table 4) showed an absorption band in the range $18815-19720 \mathrm{~cm}^{-1}$ which is assigned to the square planar ${ }^{1} \mathrm{~A}_{1 \mathrm{~g}} \rightarrow{ }^{1} \mathrm{~A}_{2 \mathrm{~g}}$ transition [48]. These d-d bands are typical of square planar Ni(II) complexes [49]. Absence of bands below $10000 \mathrm{~cm}^{-1}$ confirms square planar nature of the complex, consistent with low spin and diamagnetic ( $\mu_{\text {eff }}=0.00$ B.M.) nature [50]. 
Table 5. Antifungal activity of thiosemicarbazone compounds.

\begin{tabular}{|c|c|c|c|c|}
\hline \multirow[t]{2}{*}{ Compounds } & \multicolumn{4}{|c|}{ Diameter of inhibition zone (in mm) a } \\
\hline & $\begin{array}{l}\text { Aspergillus flavus } \\
\text { (RCMB 02568) }\end{array}$ & $\begin{array}{l}\text { Penicillium italicum } \\
\text { (RCMB 03924) }\end{array}$ & $\begin{array}{l}\text { Candida albicans } \\
\text { (RCMB 05031) }\end{array}$ & $\begin{array}{l}\text { Geotricum candidum } \\
\text { (RCMB 05097) }\end{array}$ \\
\hline$\overline{\text { TPHP }}$ & $15.6 \pm 0.58$ & $16.4 \pm 0.44$ & NA & $18.7 \pm 0.64$ \\
\hline МТPHP & $13.8 \pm 0.58$ & $14.9 \pm 0.64$ & NA & $16.7 \pm 0.72$ \\
\hline РТPHP & $14.6 \pm 0.52$ & $15.2 \pm 0.58$ & NA & $16.9 \pm 0.45$ \\
\hline$[\mathrm{Ni}(\mathrm{TPHP}) \mathrm{Cl}] \cdot \mathrm{H}_{2} \mathrm{O}$ & $17.5 \pm 0.39$ & $16.7 \pm 0.24$ & NA & $21.5 \pm 0.42$ \\
\hline [Ni(MTPHP)Cl] & $16.6 \pm 0.24$ & $14.7 \pm 0.50$ & NA & $19.1 \pm 0.60$ \\
\hline [Ni(PTPHP)Cl] & $15.2 \pm 0.68$ & $13.9 \pm 0.56$ & NA & $18.1 \pm 0.39$ \\
\hline Amphotericin (B) & $23.7 \pm 0.10$ & $21.9 \pm 0.12$ & $19.8 \pm 0.20$ & $28.7 \pm 0.22$ \\
\hline
\end{tabular}

microorganisms using $(1 \mathrm{mg} / \mathrm{mL})$ concentration of tested samples.

Table 6. Antibacterial activity as MICs and activity index of thiosemicarbazone compounds.

\begin{tabular}{|c|c|c|c|c|c|c|c|c|}
\hline \multirow[t]{2}{*}{ Compounds } & \multicolumn{2}{|c|}{$\begin{array}{l}\text { Pseudomonas aeuroginosa (Gr-) } \\
\text { (RCMB 010043) }\end{array}$} & \multicolumn{2}{|c|}{$\begin{array}{l}\text { Escherichia coli (Gr-) } \\
\text { (RCMB 010052) }\end{array}$} & \multicolumn{2}{|c|}{$\begin{array}{l}\text { Bacillus subtillis (Gr+) } \\
\text { (RCMB 010067) }\end{array}$} & \multicolumn{2}{|c|}{$\begin{array}{l}\text { Staphylococcus aureus }(\mathrm{Gr}+) \\
\text { (RCMB 010028) }\end{array}$} \\
\hline & MIC a & Activity index & MIC a & Activity index & MICa & Activity index & MIC a & Activity index \\
\hline TPHP & NA & NA & $>100$ & 63 & 15.63 & 71 & 31.25 & 56 \\
\hline MTPHP & NA & NA & $>100$ & 60 & 31.25 & 66 & 62.50 & 51 \\
\hline PTPHP & NA & NA & $>100$ & 61 & 31.25 & 68 & 31.25 & 53 \\
\hline$[\mathrm{Ni}(\mathrm{TPHP}) \mathrm{Cl}] \cdot \mathrm{H}_{2} \mathrm{O}$ & NA & NA & 3.90 & 78 & 15.63 & 70 & 7.25 & 87 \\
\hline [Ni(MTPHP)Cl] & NA & NA & 25.97 & 72 & 25.97 & 67 & 15.63 & 73 \\
\hline [Ni(PTPHP)Cl] & NA & NA & 31.25 & 70 & 31.25 & 62 & 31.25 & 69 \\
\hline Gentamicin & 31.25 & - & 1.95 & - & 0.007 & - & 0.12 & - \\
\hline
\end{tabular}

a Antibacterial activity as MICs $(\mu \mathrm{g} / \mathrm{mL})$ of tested samples against tested microorganisms.

Table 7. Antifungal activity as MICs and activity index of thiosemicarbazone compounds.

\begin{tabular}{|c|c|c|c|c|c|c|c|c|}
\hline \multirow[t]{3}{*}{ Compounds } & \multicolumn{8}{|c|}{ Diameter of inhibition zone (in $\mathrm{mm}$ ) } \\
\hline & \multicolumn{2}{|c|}{$\begin{array}{l}\text { Aspergillus fumigatus } \\
\text { (RCMB 02568) }\end{array}$} & \multicolumn{2}{|c|}{$\begin{array}{l}\text { Pencicillium italicum } \\
\text { (RCMB 03924) }\end{array}$} & \multicolumn{2}{|c|}{$\begin{array}{l}\text { Candida albicans } \\
\text { (RCMB 05031) }\end{array}$} & \multicolumn{2}{|c|}{$\begin{array}{l}\text { Geotricum candidum } \\
\text { (RCMB 05097) }\end{array}$} \\
\hline & MIC a & Activity index & MIC a & Activity index & MIC a & Activity index & MIC a & Activity index \\
\hline TPHP & 62.50 & 54 & 31.25 & 75 & NA & NA & 15.63 & 65 \\
\hline МТPHP & $>100$ & 48 & 62.50 & 68 & NA & NA & 31.25 & 58 \\
\hline РТРНP & $>100$ & 51 & 62.50 & 69 & NA & NA & 31.25 & 59 \\
\hline$[\mathrm{Ni}(\mathrm{TPHP}) \mathrm{Cl}] \cdot \mathrm{H}_{2} \mathrm{O}$ & 15.63 & 74 & 25.97 & 76 & NA & NA & 7.81 & 75 \\
\hline [Ni(MTPHP)Cl] & 31.25 & 70 & 31.25 & 69 & NA & NA & 15.63 & 67 \\
\hline [Ni(PTPHP) Cl] & 62.50 & 64 & 62.50 & 65 & NA & NA & 31.25 & 63 \\
\hline Amphotericin (B) & 1.95 & - & 3.9 & - & 7.81 & & 0.06 & - \\
\hline
\end{tabular}

a Antifungal activity as MICs $(\mu \mathrm{g} / \mathrm{mL})$ of tested samples against tested microorganisms.

\subsection{Antimicrobial activity}

To assess the biological potential of the synthesized compounds, the thiosemicarbazone ligands and their metal complexes were tested against different species of bacteria and fungi. In testing the antimicrobial activity of these compounds, we used more than one test organism to increase the chance of detecting antibiotic principles in tested materials. The organisms used in the present investigations included two Gram positive (Staphylococcus aureus and Bacillus subtillis) and two Gram negative (Pseudomonas aeruguinosa and Escherichia coli). The diffusion agar technique was used to evaluate the antibacterial activity of the synthesized mixed ligand complexes [51-54]. The medium used for growing the culture was nutrient agar. The results of the antibacterial activity of the synthesized compounds are recorded in Tables 4-7. Metal ions are adsorbed on the cell walls of the microorganisms, disturbing the respiration processes of the cells and thus blocking the protein synthesis that is required for further growth of the organisms. Hence, metal ions are essential for the growth-inhibitory effects [55]. The synthesized compounds were found to be more toxic compared with their parent free ligands against the same micro-organism and under the identical experimental conditions.

According to Overtone's concept of cell permeability, the lipid membrane that surrounds the cell favors the passage of only lipid-soluble materials, so lipophilicity is an important factor controlling the antifungal activity. Upon chelating, the polarity of the metal ion will be reduced due to the overlap of the ligand orbitals and partial sharing of the positive charge of the metal ion with donor groups. In addition, chelation allows for the delocalization of $\pi$-electrons over the entire chelate ring and enhances the lipophilicity of the complexes. This increased lipophilicity facilitates the penetration of the complexes into lipid membranes, further restricting proliferation of the microorganisms. The variation in the effectiveness of different compounds against different organisms depends either on the impermeability of the microbial cells or on differences in the ribosomes of the cells [56]. All of the metal complexes possess higher antifungal activity than the ligand $[57,58]$. Although the exact biochemical mechanism is not completely understood, the mode of action of antimicrobials may involve various targets in the microorganisms. These targets include the following.

(i) The higher activity of the metal complexes may be due to the different properties of the metal ions upon chelation. The polarity of the metal ions will be reduced due to the overlap of the ligand orbitals and partial sharing of the positive charge of the metal ion with donor groups. Thus, chelation enhances the penetration of the complexes into lipid membranes and the blockage of metal binding sites in the enzymes of the microorganisms [59].

(ii) Tweedy's chelation theory predicts that chelation reduces the polarity of the metal atom mainly because of partial sharing of its positive charge with donor groups and possible electron delocalization over the entire ring. This consequently increases the lipophilic character of the chelates, favoring their permeation through the lipid layers of the bacterial membrane [60].

(iii) Interference with the synthesis of cellular walls, causing damage that can lead to altered cell permeability characteristics or disorganized lipoprotein arrangements, ultimately resulting in cell death. 
Table 8. Some energetic properties of thiosemicarbazone compounds calculated by PM3 method.

\begin{tabular}{l|llllll}
\hline Ligand & $\begin{array}{l}\text { Total energy } \\
\text { (kcal/mol) }\end{array}$ & $\begin{array}{l}\text { Binding } \\
\text { energy (kcal/mol) }\end{array}$ & $\begin{array}{l}\text { Electronic energy } \\
\text { (kcal/mol) }\end{array}$ & $\begin{array}{l}\text { Dipole moment } \\
\text { (Debye) }\end{array}$ & HOMO (eV) & LUMO (eV) \\
\hline TPHP & -54861.71 & -2887.45 & -333133.43 & 4.81 & -8.66 \\
MTPHP & -54869.01 & -2894.00 & -339543.84 & 6.14 & -8.58 \\
PhTPHP & -72667.78 & -4097.17 & -510622.23 & 5.17 & -8.58 \\
{$[\mathrm{Ni}(\mathrm{TPHP}) \mathrm{Cl}] . \mathrm{H}_{2} \mathrm{O}$} & -85886.52 & -3147.44 & -499165.10 & 5.26 & -8.97 \\
{$[\mathrm{Ni}(\mathrm{MTPHP}) \mathrm{Cl}]$} & -89303.08 & -3395.96 & -539051.05 & 5.53 & -1.13 \\
{$[\mathrm{Ni}(\mathrm{PTPHP}) \mathrm{Cl}]$} & -103685.35 & -4349.51 & -701336.87 & 5.77 & -1.41 \\
\hline
\end{tabular}

(iv) Deactivation of various cellular enzymes that play a vital role in the metabolic pathways of these microorganisms.

(v) Denaturation of one or more cellular proteins, causing the normal cellular processes to be impaired.

(vi) Formation of a hydrogen bond through the azomethine group with the active centers of various cellular constituents, resulting in interference with normal cellular processes [61].

The mode of action of the compounds may involve formation of a hydrogen bond through the azomethine group $(>\mathrm{C}=\mathrm{N}$-) with the active centers of various cellular constituents, resulting in interference with normal cellular processes $[62,63]$. The tested complexes were more active against Grampositive than Gram-negative bacteria [34], it may be concluded that the antibacterial activity of the compounds is related to cell wall structure of the bacteria. It is possible because the cell wall is essential to the survival of bacteria and some antibiotics are able to kill bacteria by inhibiting a step in the synthesis of peptidoglycan. Gram-positive bacteria possess a thick cell wall containing many layers of peptidoglycan and teichoic acids, but in contrast, Gram negative bacteria have a relatively thin cell wall consisting of a few layers of peptidoglycan surrounded by a second lipid membrane containing lipopolysaccharides and lipoproteins. These differences in cell wall structure can produce differences in antibacterial susceptibility and some antibiotics can kill only Gram-positive bacteria and is ineffective against Gram-negative pathogens $[64,65]$. It is worth noting that the comparison of antibacterial activity of the compounds against the selected types of bacteria (Figure 1) indicates that TPHP > MTPHP > PTPHP. Thus, the presence of substituents at position N(4) of the thiosemicarbazone moiety affects the biological activity. The activity index of the synthesized compounds was calculated against the different selected types of bacteria and it was found that $\mathrm{Ni}(\mathrm{II})$ complex have the highest activity index against Bacillus subtillis. The synthesized thiosemicarbazone compounds and their complexes are inactive against Candida albicans. The MIC values for Ni-TPHP complex versus Geotricum candidum and Escherichia coli are 7.81 and $3.90 \mu \mathrm{g} / \mathrm{mL}$ respectively. The antifungal activity was given in Figure 2 .

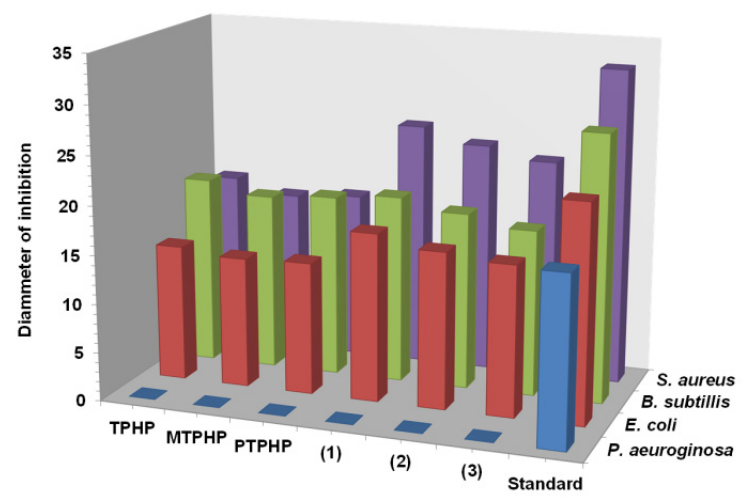

Figure 1. Antibacterial activity of Ni(II)-complexes.

\subsection{Molecular modelling}

In the absence of a crystal structure, to obtain the molecular conformation of a compound, energy minimization studies were carried out on the basis of the semi-empirical PM3 level provided by HyperChem 7.5 software. The calculated dipole moment, total energy $\left(E_{T}\right)$, binding energy $\left(E_{B}\right)$, isolated atomic energy $\left(E_{I A}\right)$, electronic energy $\left(E_{E}\right)$ and core-core interaction $\left(I_{C-c}\right)$ after geometrical optimization of the structures of complexes were given in Table 8.

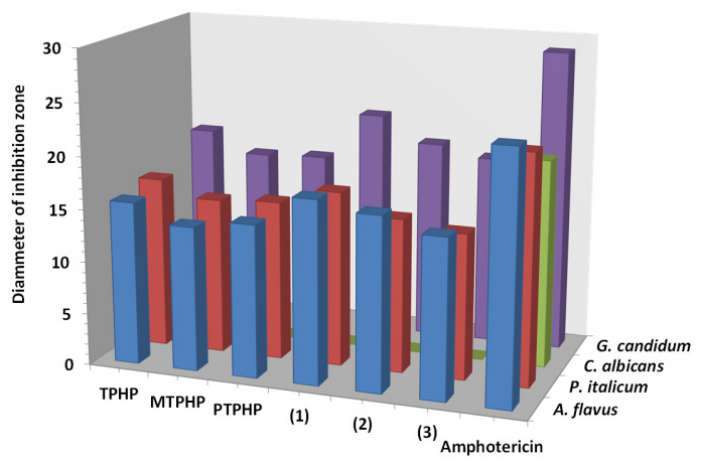

Figure 2. Antifungal activity of Ni(II)-complexes.

\subsubsection{Bond length and bond angle calculations}

The thiosemicarbazone ligands might exhibits two tautomeric, thione and thiol, forms. It behaves as a tridentate ligand with ONS coordination sites. The ligand bond lengths and bond angles of Ni-TPHP as a representative example of thiosemicarbazone complexes are given in Table 9. A drawing of $\mathrm{Ni}(\mathrm{II})$ complexes with the atomic numbering scheme is shown in Figures 3-5 while selected bond lengths and angles are given in Table 10. The coordination results in the changes of bond lengths and angles of the thiosemicarbazone moiety, as expected. The C-S bond length increases from 1.63(3) $\AA$ in the free TPHP ligand to $1.74 \AA$ in Ni-TPHP complex. Similarly N$\mathrm{C}(\mathrm{S})$ bond suffers a significant decrease from $1.43 \AA$ seen in the free TPHP ligand to $1.37 \AA$ in Ni-TPHP complex. These changes indicate the coordination of the deprotonated sulfur after enethiolization. This means that, C-S distances (Table 10) which are in the range of single bond character being some of the largest found for thiosemicarbazone complexes (typical bond lengths being $\mathrm{C}\left(s p^{2}\right)-\mathrm{S} 1.706 \AA$ in $(\mathrm{MeS})_{2} \mathrm{C}=\mathrm{C}(\mathrm{SMe})_{2}$ and $\mathrm{C}=\mathrm{S} 1.630 \AA$ in naphthylphenylthioketone) $[63,66]$. This also confirms the IR and spectral data which assumed that the $\mathrm{C}=\mathrm{S}$ on coordination gains C-S character. Similar results are observed for both MTPHP and PTPHP thiosemicarbazone ligands and their complexes (Table 10). The other bond lengths and angles also suffer some changes, but not significantly. The bond angles around nickel are between $87-92^{\circ}$. The bond angles around the $\mathrm{Ni}(\mathrm{II})$ center $\left(\sim 90^{\circ}\right)$ prove that the geometric is square planar as proposed by the different tools of analysis mentioned previously. Finally, from the interpretation of elemental analysis, magnetic susceptibility measurements at room temperature, conductivity measurements, spectral data and QM calculations, it is possible to draw up the tentative structures of the metal complexes. 
Table 9. Bond distances and angles for Ni-TPHP.

\begin{tabular}{|c|c|c|c|c|c|}
\hline Atoms & Bond distances (Å) & Atoms & Angle (o) & Atoms & Angle (o) \\
\hline $\mathrm{Ni}(17)-\mathrm{Cl}(18)$ & 2.224 & $\mathrm{Cl}(18)-\mathrm{Ni}(17)-\mathrm{S}(15)$ & 87.787 & $\mathrm{H}(24)-\mathrm{N}(7)-\mathrm{N}(8)$ & 106.077 \\
\hline $\mathrm{C}(16)-\mathrm{H}(30)$ & 1.099 & $\mathrm{Cl}(18)-\mathrm{Ni}(17)-\mathrm{N}(11)$ & 178.407 & $\mathrm{H}(24)-\mathrm{N}(7)-\mathrm{C}(5)$ & 118.001 \\
\hline $\mathrm{C}(16)-\mathrm{H}(29)$ & 1.098 & $\mathrm{Cl}(18)-\mathrm{Ni}(17)-\mathrm{N}(8)$ & 92.496 & $N(8)-N(7)-C(5)$ & 122.158 \\
\hline $\mathrm{C}(16)-\mathrm{H}(28)$ & 1.099 & $\mathrm{~S}(15)-\mathrm{Ni}(17)-\mathrm{N}(11)$ & 92.409 & $H(23)-C(6)-C(5)$ & 121.304 \\
\hline $\mathrm{S}(15)-\mathrm{Ni}(17)$ & 2.201 & $\mathrm{~S}(15)-\mathrm{Ni}(17)-\mathrm{N}(8)$ & 179.610 & $\mathrm{H}(23)-\mathrm{C}(6)-\mathrm{C}(1)$ & 119.137 \\
\hline $\mathrm{N}(14)-\mathrm{H}(27)$ & 0.989 & $\mathrm{~N}(11)-\mathrm{Ni}(17)-\mathrm{N}(8)$ & 87.316 & $C(5)-C(6)-C(1)$ & 119.559 \\
\hline $\mathrm{N}(14)-\mathrm{H}(26)$ & 0.990 & $\mathrm{H}(30)-\mathrm{C}(16)-\mathrm{H}(29)$ & 107.659 & $N(7)-C(5)-C(6)$ & 122.535 \\
\hline$C(13)-S(15)$ & 1.749 & $\mathrm{H}(30)-\mathrm{C}(16)-\mathrm{H}(28)$ & 107.526 & $\mathrm{~N}(7)-\mathrm{C}(5)-\mathrm{C}(4)$ & 117.236 \\
\hline$C(13)-N(14)$ & 1.352 & $\mathrm{H}(30)-\mathrm{C}(16)-\mathrm{C}(10)$ & 110.454 & $C(6)-C(5)-C(4)$ & 120.082 \\
\hline$N(12)-C(13)$ & 1.379 & $\mathrm{H}(29)-\mathrm{C}(16)-\mathrm{H}(28)$ & 107.661 & $H(22)-C(4)-C(5)$ & 120.847 \\
\hline $\mathrm{N}(11)-\mathrm{Ni}(17)$ & 1.818 & $\mathrm{H}(29)-\mathrm{C}(16)-\mathrm{C}(10)$ & 113.065 & $\mathrm{H}(22)-\mathrm{C}(4)-\mathrm{C}(3)$ & 119.551 \\
\hline $\mathrm{N}(11)-\mathrm{N}(12)$ & 1.349 & $\mathrm{H}(28)-\mathrm{C}(16)-\mathrm{C}(10)$ & 110.268 & $C(5)-C(4)-C(3)$ & 119.602 \\
\hline$C(10)-C(16)$ & 1.478 & $\mathrm{Ni}(17)-\mathrm{S}(15)-\mathrm{C}(13)$ & 90.215 & $\mathrm{H}(21)-\mathrm{C}(3)-\mathrm{C}(4)$ & 119.677 \\
\hline$C(10)-N(11)$ & 1.323 & $\mathrm{H}(27)-\mathrm{N}(14)-\mathrm{H}(26)$ & 118.227 & $\mathrm{H}(21)-\mathrm{C}(3)-\mathrm{C}(2)$ & 119.940 \\
\hline $\mathrm{C}(9)-\mathrm{H}(25)$ & 1.102 & $\mathrm{H}(27)-\mathrm{N}(14)-\mathrm{C}(13)$ & 119.366 & $C(4)-C(3)-C(2)$ & 120.383 \\
\hline$C(9)-C(10)$ & 1.470 & $\mathrm{H}(26)-\mathrm{N}(14)-\mathrm{C}(13)$ & 122.380 & $H(20)-C(2)-C(3)$ & 120.031 \\
\hline $\mathrm{N}(8)-\mathrm{Ni}(17)$ & 1.837 & $\mathrm{~S}(15)-\mathrm{C}(13)-\mathrm{N}(14)$ & 123.742 & $\mathrm{H}(20)-\mathrm{C}(2)-\mathrm{C}(1)$ & 120.057 \\
\hline$N(8)-C(9)$ & 1.315 & $\mathrm{~S}(15)-\mathrm{C}(13)-\mathrm{N}(12)$ & 124.195 & $C(3)-C(2)-C(1)$ & 119.912 \\
\hline $\mathrm{N}(7)-\mathrm{H}(24)$ & 1.096 & $\mathrm{~N}(14)-\mathrm{C}(13)-\mathrm{N}(12)$ & 112.064 & $\mathrm{H}(19)-\mathrm{C}(1)-\mathrm{C}(6)$ & 119.581 \\
\hline$N(7)-N(8)$ & 1.360 & $\mathrm{C}(13)-\mathrm{N}(12)-\mathrm{N}(11)$ & 113.748 & $\mathrm{H}(19)-\mathrm{C}(1)-\mathrm{C}(2)$ & 119.960 \\
\hline $\mathrm{C}(6)-\mathrm{H}(23)$ & 1.100 & $\mathrm{Ni}(17)-\mathrm{N}(11)-\mathrm{N}(12)$ & 119.419 & $C(6)-C(1)-C(2)$ & 120.459 \\
\hline$C(5)-N(7)$ & 1.446 & $\mathrm{Ni}(17)-\mathrm{N}(11)-\mathrm{C}(10)$ & 112.905 & & \\
\hline$C(5)-C(6)$ & 1.399 & $N(12)-N(11)-C(10)$ & 127.649 & & \\
\hline $\mathrm{C}(4)-\mathrm{H}(22)$ & 1.098 & $\mathrm{C}(16)-\mathrm{C}(10)-\mathrm{N}(11)$ & 127.228 & & \\
\hline$C(4)-C(5)$ & 1.402 & $\mathrm{C}(16)-\mathrm{C}(10)-\mathrm{C}(9)$ & 119.237 & & \\
\hline $\mathrm{C}(3)-\mathrm{H}(21)$ & 1.095 & $\mathrm{~N}(11)-\mathrm{C}(10)-\mathrm{C}(9)$ & 113.535 & & \\
\hline$C(3)-C(4)$ & 1.389 & $\mathrm{H}(25)-\mathrm{C}(9)-\mathrm{C}(10)$ & 120.713 & & \\
\hline $\mathrm{C}(2)-\mathrm{H}(20)$ & 1.095 & $\mathrm{H}(25)-\mathrm{C}(9)-\mathrm{N}(8)$ & 125.777 & & \\
\hline $\mathrm{C}(2)-\mathrm{C}(3)$ & 1.392 & $\mathrm{C}(10)-\mathrm{C}(9)-\mathrm{N}(8)$ & 113.507 & & \\
\hline $\mathrm{C}(1)-\mathrm{H}(19)$ & 1.095 & $\mathrm{Ni}(17)-\mathrm{N}(8)-\mathrm{C}(9)$ & 112.649 & & \\
\hline$C(1)-C(6)$ & 1.390 & $\mathrm{Ni}(17)-\mathrm{N}(8)-\mathrm{N}(7)$ & 115.307 & & \\
\hline$C(1)-C(2)$ & 1.390 & $\mathrm{C}(9)-\mathrm{N}(8)-\mathrm{N}(7)$ & 131.872 & & \\
\hline
\end{tabular}

Table 10. Comparison of bond length $(\AA)$ and angles $\left({ }^{\circ}\right)$ for free thiosemicarbazone ligands and their Ni(II)-complexes.

\begin{tabular}{|c|c|c|c|c|c|c|}
\hline 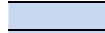 & TPHP & {$[\mathrm{Ni}(\mathrm{TPHP}) \mathrm{Cl}] \cdot \mathrm{H}_{2} \mathrm{O}$} & MTPHP & [Ni(MTPHP)Cl] & PTPHP & [Ni(PTPHP)Cl] \\
\hline \multicolumn{7}{|c|}{ Bond length } \\
\hline C-S & 1.631 & 1.741 & 1.631 & 1.730 & 1.658 & 1.761 \\
\hline $\mathrm{N}-\mathrm{C}(\mathrm{S})$ & 1.437 & 1.371 & 1.437 & 1.383 & 1.439 & 1.371 \\
\hline $\mathrm{Ni}-\mathrm{S}$ & - & 2.202 & - & 2.192 & - & 2.199 \\
\hline $\mathrm{Ni}-\mathrm{Cl}$ & - & 2.221 & - & 2.228 & - & 2.224 \\
\hline $\mathrm{Ni}-\mathrm{N}(12)$ & - & 1.812 & - & 1.830 & - & 1.818 \\
\hline $\mathrm{Ni}-\mathrm{N}(8)$ & - & 1.831 & - & 1.816 & - & 1.836 \\
\hline \multicolumn{7}{|c|}{ Bond angle } \\
\hline $\mathrm{N}-\mathrm{Ni}-\mathrm{N}$ & - & 87.31 & - & 88.05 & - & 87.41 \\
\hline $\mathrm{N}-\mathrm{Ni}-\mathrm{S}$ & - & 92.40 & - & 90.65 & - & 91.85 \\
\hline $\mathrm{N}-\mathrm{Ni}-\mathrm{Cl}$ & - & 92.49 & - & 92.30 & - & 92.54 \\
\hline$\underline{\mathrm{Cl}-\mathrm{Ni}-\mathrm{S}}$ & - & 87.78 & - & 88.99 & - & 88.19 \\
\hline
\end{tabular}

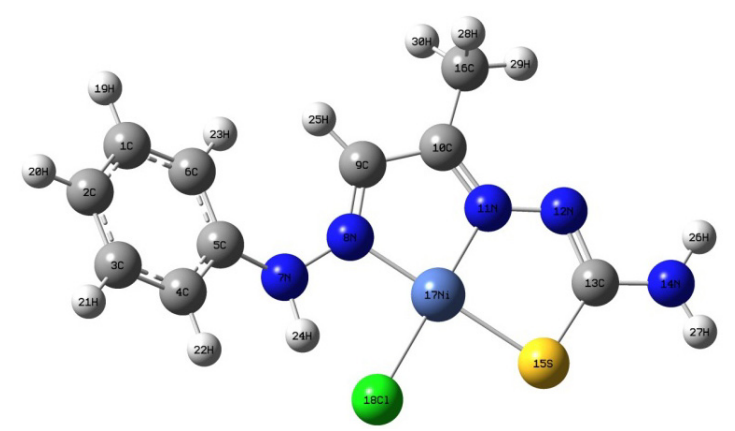

Figure 3. The molecular structure of [Ni(TPHP)Cl] (1) along with the atom numbering scheme.

\subsubsection{Molecular parameters}

Quantum chemical parameters of organic compounds are obtained from calculations, such as the energy of the highest

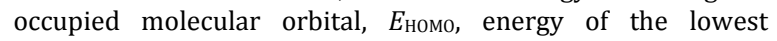

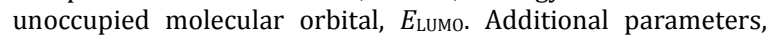
such as separation energies $(\Delta E)$, absolute electronegativitiy $(\chi)$, chemical potentials (Pi), absolute hardness ( $\eta)$, absolute softness $(\sigma)$, global electrophilicity $(\omega)$ [67-71], global softness
(S) and additional electronic charge $\left(\Delta N_{\max }\right)$ have been calculated [72]. The concepts of the parameters $\chi$ and Pi are related to each other. The inverse of the global hardness is designated as the softness $\sigma$ [73]. From the obtained data (Table 11) we can deduced that:

a) Absolute hardness $(\eta)$ and softness $(\sigma)$ are important properties to measure the molecular stability and reactivity. A hard molecule has a large energy gap and a soft molecule has a small energy gap. Soft molecules are more reactive than hard ones because they could easily offer electrons to an acceptor. In a complex formation system, the ligand acts as a Lewis base while the metal ion acts as a Lewis acid. Metal ions are soft acids and thus soft base ligands are most effective for complex formation. Accordingly, it is concluded that TPHP, with a proper $\sigma$ value has a good tendency to chelate metal ions effectively [74]. This is also confirmed from the calculated chemical potential Pi values.

b) The reactivity index measures the stabilization in energy when the system acquires an additional electronic charge $\left(\Delta \mathrm{N}_{\max }\right)$ from the environment. , The electrophilicity index is positive quantity and the direction of the charge transfer is completely determined by the electronic chemical potential (Pi) of the molecule because an electrophile is a chemical 
Table 11. The calculated quantum chemical parameters of the ligands and their Ni(II) complexes.

\begin{tabular}{|c|c|c|c|c|c|c|c|c|c|}
\hline Compound & HOMO (eV) & LUMO (eV) & $\chi$ & $\eta$ & $\sigma$ & $\mathbf{P i}$ & $\Delta \mathbf{E}$ & $\omega$ & $\Delta \mathbf{N}_{\max }$ \\
\hline TPHP(Thione) & -8.66 & -1.05 & 4.860 & 3.805 & 0.260 & -4.860 & 7.61 & 3.100 & 1.280 \\
\hline TPHP(Thiol) & -8.59 & -0.61 & 4.600 & 3.990 & 0.251 & -4.600 & 7.98 & 2.652 & 1.153 \\
\hline MTPHP(Thione) & -8.58 & -0.97 & 4.775 & 3.805 & 0.263 & -4.775 & 7.61 & 2.996 & 1.255 \\
\hline MTPHP(Thiol) & -8.65 & -0.61 & 4.630 & 4.020 & 0.249 & -4.630 & 8.04 & 2.666 & 1.152 \\
\hline PTPHP(Thione) & -8.58 & -1.13 & 4.855 & 3.725 & 0.268 & -4.855 & 7.45 & 3.164 & 1.303 \\
\hline PTPHP(Thiol) & -8.62 & -0.71 & 4.665 & 3.955 & 0.253 & -4.665 & 7.91 & 2.751 & 1.180 \\
\hline$[\mathrm{Ni}(\mathrm{TPHP}) \mathrm{Cl}] \cdot \mathrm{H}_{2} \mathrm{O}$ & -8.42 & -1.41 & 4.915 & 3.505 & 0.285 & -4.915 & 7.01 & 3.446 & 1.402 \\
\hline [Ni(MTPHP)Cl] & -8.37 & -1.40 & 4.885 & 3.485 & 0.287 & -4.885 & 6.97 & 3.424 & 1.402 \\
\hline [Ni(PTPHP)Cl] & -8.40 & -1.49 & 4.945 & 3.455 & 0.289 & -4.945 & 6.91 & 3.539 & 1.431 \\
\hline
\end{tabular}

species capable of accepting electrons from the environment and its energy must decrease upon accepting electronic charge. Therefore, the electronic chemical potential must be negative, exactly as supported by the values in Table 11 .

c) The highest occupied molecular orbital (HOMO) and lowest unoccupied molecular orbital (LUMO) are very popular quantum chemical parameters. These molecular orbitals are also called the frontier molecular orbitals (FMOs) and determine the way of interaction for the molecule with other species. The FMOs are important in molecular reactivity. The HOMO is the orbital that could act as an electron donor, since it is the highest energy orbital containing electrons. The LUMO is the orbital that could act as the electron accepter, since it is the lowest energy orbital that can accept electrons. The energies of the HOMO and LUMO are negative, which indicate the title thiosemicarbazone molecules are stable [75].

d) Lower HOMO energy values show that the molecule donating electron ability is weaker. On contrary, a higher HOMO energy implies that the molecule is a good electron donor. The LUMO energy presents the ability of a molecule receiving an electron.

e) From the calculations of the binding energy we notice that there is an increase of the value of the calculated binding energy of complexes compared to that of the free thiosemicarbazone ligands which indicates that the stability of the formed metal complexes is higher than that of the corresponding ligands.

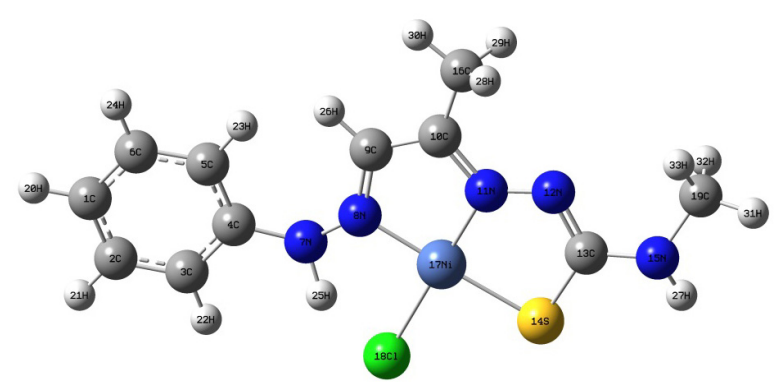

Figure 4. The molecular structure of [Ni(MTPHP)Cl] (2) along with the atom numbering scheme.

\subsection{Molecular modeling and biological activity}

Theoretical calculations were performed in order to investigate physico-chemical properties that may be related to the antimicrobial action of the studied compounds. Therefore, structure activity relationship (SAR) theoretical calculations were performed in order to investigate physico-chemical properties that may be related to the antimicrobial action of the studied compounds. Properties of interest in this study were the highest occupied molecular orbital (HOMO) and lowest unoccupied molecular orbital (LUMO) energies and the dipole moments, which were correlated to the determined zone of inhibition and MIC values. The HOMO and LUMO energies are related to ionization potential and electron affinity, respectively. These frontier orbitals are associated to the molecule's reactivity. HOMO energy is closely related to reactivity to electrophilic attack while LUMO energy is closely related to reactivity to nucleophilic attack. Additionally, the dipole moment may give some insight on the degree of hydrophobicity/hydrophilicity of the compounds i.e. dipole moment is a very useful parameter for determining the penetration through cell membrane and for the speed of excretion. In general HOMO and LUMO energies of all thiosemicarbazones were very close. Ni-TPHP complex (1), which presented the lowest value of HOMO energy among all $\mathrm{Ni}(\mathrm{II})$ complexes, showed the highest biological activity against all selected types of bacteria and fungi.

Additionally, the dipole moment may give some insight on the degree of hydrophobicity/hydrophilicity of the compounds. SAR studies suggested that there is an inverse correlation between the dipole moment and the activity of the thiosemicarbazones against the studied bacterial and fungal species. As dipole moment decreases the polarity decreases and in turn the lipophilic nature of the compound increases, which favors its permeation more efficiently through the lipid layer of the microorganism [76], thus destroying them more aggressively. From the data given in Table 8, the dipole moment of $\mathrm{Ni}(\mathrm{II})$ complexes is lower than the corresponding free thiosemicarbazone ligands. Thus, the lipophilicity of the $\mathrm{Ni}(\mathrm{II})$ complexes is larger than the free thiosemicarbazone ligands, which in turn deactivates enzymes responsible for respiration processes of the tested micro-organisms more than the ligands i.e. the formation of a lipophilic complex, could enhance its penetration through the cytoplasmic membrane, and consequently increase the cellular uptake of nickel ions by bacterial cells. Consequently, the tested complexes were more biologically active than the free thiosemicarbazone ligands.

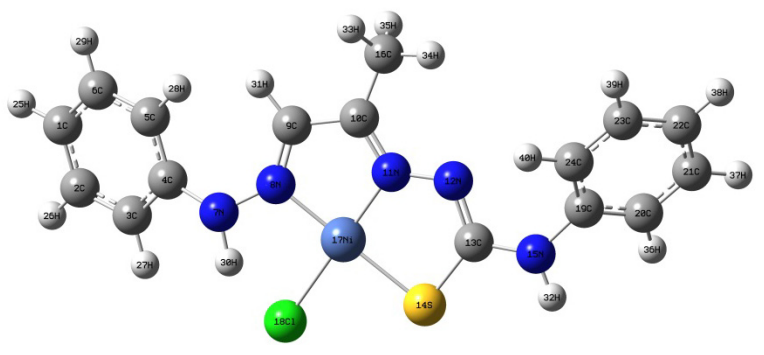

Figure 5. The molecular structure of [Ni(PTPHP) Cl] (3) along with the atom numbering scheme.

\section{Conclusions}

The condensation reaction of 1-(phenyl-hydrazono)propan-2-one (PHP) with thiosemicarbazide, $N$-methylthiosemicarbazide and $N$-phenylthiosemicarbazide in the molar ratio (1:1) afforded the corresponding three novel thiosemicarbazone compounds. The IR spectra showed that, thiosemicarbazone compounds present in the thione form in the solid state. In the absence of X-ray single crystal data of the 
current synthesized complexes and based on the physicchemical studies and geometrical optimization, a tentative structure could be proposed as shown in Figures 3-5. Ni(II)complexes are formulated as $[\mathrm{NiLCl}] \cdot \mathrm{nH}_{2} \mathrm{O}$ where $\mathrm{L}$ is the deprotonated thiosemicarbazone ligand. In these complexes the thiosemicarbazone ligands are coordinated to the metal (II) ion as a tridentate anion, coordinating via the two azomethine nitrogen atoms and the thiolate sulfur atom after deprotonation. From elemental analysis, IR, spectral, thermal analysis, magnetic and conductance measurements, all $\mathrm{Ni}(\mathrm{II})$-complexes are nonelectrolytes with a square planar structure. Quantum calculations calculations prove also that the $\mathrm{Ni}(\mathrm{II})$-complexes have square planar geometry. Ni(II)-complexes have nearly the same thermal stability due to they are iso-structural. In this work, it was found that the three compounds with different substituents show significantly different levels of biological activity. The antibacterial, antifungal, screening data revealed that newly generated compounds are potential antimicrobial agents. SAR studies suggested that there is an inverse correlation between the dipole moment and the activity of the thiosemicarbazones against the studied bacterial and fungal species. In summary, compounds discussed in this article, represent a good model for comparison to establish a good correlation of structure and activity. The relationship between structural and biological properties has been explored which could be helpful in designing more potent antibacterial agents.

\section{References}

[1]. Berber, I.; Cokmus, C.; Atalan, E. Mikrobiologia 2003, 72, 54-55.

[2]. Harbottle, H.; Thakur, S.; Zhao, White, D. G. Anim. Biotechol. 2006, 17, 111-124.

[3]. Berger, S. Horm. Metab. Res. 1985, 17, 111-115.

[4]. Lakshmi, B.; Avaji, P. G.; Shivananda, K. N.; Nagella, P.; Manohar, S. H.; Mahendra, K. N. Polyhedron 2011, 30, 1507-1515.

[5]. Chan, J.; Huang, Y.; Liu, G.; Afrasiabi, Z.; Sinn, E.; Padhye, S.; Ma, Y. Toxicol. Appl. Pharm. 2004, 197, 40-48.

[6]. Duffy, K. J.; Shaw, A. N.; Delorme, E.; Dillon, S. B.; Erickson-Miller, C.; Giampa, L.; Huang, Y.; Keenan, R. M.; Lamb, P.; Liu, N.; Miller, S. G.; Price, A. T.; Rosen, J.; Smith, H.; Wiggall, K. J.; Zhang, L.; Luengo, J. I. J. Med. Chem. 2002, 45, 3573-3575.

[7]. Du, X.; Guo, C.; Hansel, E.; Doyle, P. S.; Caffrey, C. R.; Holler, T. P.; McKerrow, J. H.; Cohen, F. E. J. Med. Chem. 2002, 45, 2695-2707.

[8]. Kovala-Demertzi, D.; Demertzis, M. A.; Filiou, E.; Pantazaki, A. A.; Yadav, P. N.; Miller, J. R.; Zheng, Y.; Kyriakidis, D. A. Biometals 2003, 16, 411-419.

[9]. Scovill, J. P.; Klayman, D. L.; Franchino, D. G. J. Med. Chem. 1982, 25, 1261-1264.

[10]. Klayman, L.; Scovill, J. P.; Bartosevich, J. F.; Bruce, J. J. Med. Chem. 1983, 26, 35-39.

[11]. Demertzi, D. K.; Demertzis, M. A.; Miller, J. R.; Papadopoulou, C.; Dodorou, C.; Filousis, G. J. Inorg. Biochem. 2001, 86, 555-563.

[12]. Singh, P. K.; Kumar, D. N. Spectrochim. Acta A 2006, 64, 853-858.

[13]. Sha, J. J.; Zhang, M. H.; Jiang, Y. J. The handbook of new breed pesticide of overseas, Beijing: Chemical Industry Press, 1993.

[14]. Sondhi, S. M.; Dinodia, M.; Kumar, A. Bioorg. Med. Chem. 2006, 14, 4657-4663.

[15]. El-Sherif, A. A. Inorg. Chim. Acta 2009, 362, 4991-5000.

[16]. Booth, B. A.; Moore, E. C.; Sartorelli, A. C. Cancer Res. 1971, 31, 228 234.

[17]. Labisbal, E.; Haslow, K. D.; Sousa-Pedrares, A.; Valdes-Martinez, J.; Hernandez-Ortega, S.; West, D. X. Polyhedron 2003, 22, 2831-2837.

[18]. John, R. P.; Sreekanth, A.; Rajakannan, V.; Ajith, T. A.; Kurup, M. R. P. Polyhedron 2004, 23, 2549-2559.

[19]. Belicchi-Ferrari, M.; Bisceglie, F.; Casoli, C.; Durot, S.; MorgensternBadarau, I.; Pelosi, G.; Pilotti, E.; Pinelli, S.; Tarasconi, P. J. Med. Chem. 2005, 5, 1671-1675.

[20]. Lobana, T. S.; Rekha, R.; Butcher, R. J.; Castineiras, A.; Bermejo, E.; Bharatam, P. V. Inorg. Chem. 2006, 45, 1535-1542.

[21]. Joseph, M.; Kuriakose, M.; Kurup, M. R. P.; Suresh, E.; Kishore, A.; Bhat, S. G. Polyhedron 2006, 25, 61-70.

[22]. Prathimaa, B.; Raoa, Y. S.; Reddy, S. A.; Reddy, Y. P.; Reddy, A. V. J. Spectrochim. Acta A 2010, 77, 248-252.

[23]. Zheng, Y.; Yi, Y.; Wang, Y.; Zhang, W.; Du, M. Bioorg. Med. Chem. Lett. 2006, 16, 4127-4129.

[24]. Rabjohn, N. Organic Synthesis, Collective Volume 4, John Wiley and Sons Inc., 1963.

[25]. HyperChem version 7. 5 Hypercube, Inc., 2003.

[26]. Bauer, A. W.; Kirby, W. M.; Sherris, C.; Turck, M. Am. J. Clin. Pathol. 1966, 45, 493-496.
[27]. Pfaller, M. A.; Burmeister, L.; Bartlett, M. A.; Rinaldi, M. G. J. Clin Microbiol. 1988, 26, 1437-1441.

[28]. National Committee for Clinical Laboratory Standards, Methods for dilution antimicrobial susceptibility tests for bacteria that grow aerobically. Approved standard M7-A3, Villanova, Pa (1993).

[29]. National Committee for Clinical Laboratory Standards, Reference method for broth dilution antifungal susceptibility testing of conidium-forming filamentous fungi: Proposed standard M38-A, NCCLS, Wayne, PA, USA, 2002.

[30]. National Committee for Clinical Laboratory Standards, Method for antifungal disk diffusion susceptibility testing of yeast: Proposed guideline M44-P. NCCLS, Wayne, PA, USA, 2003.

[31]. Liebowitz, L. D.; Ashbee, H. R.; Evans, E. G. V.; Chong, Y.; Mallatova, N.; Zaidi, M.; Gibbs, D. Microbiol. Infet. Dis. 2001, 24, 27-33.

[32]. Matar, M. J.; Ostrosky-Zeichner, L.; Paetznick, V. L.; Rodriguez, J. R.; Chen, E.; Rex, J. H. Antimicrob. Agents Chemother. 2003, 47, 16471651.

[33]. Swami, M. P.; Gupta, D.; Mohan, M.; Srivastava, A. K. Prog. Natl. Acad. Sci. India A 1980, 50(3), 176-181.

[34]. West, D. X.; Yang, Y. H.; Goldberg, T. L.; Liberta, A. E.; Valdes-Matines, J.; Hernandez-Ortega, S. Polyhedron 1995, 14, 1681-1693.

[35]. West, D. X.; Liberta, A. E.; Padhye, S. B.; Chikate, R. C.; Sonawane, P. B.; Kumbhar, A. S.; Yerande, R. G. Coord. Chem. Rev. 1993, 123, 49-71.

[36]. Kurup, M. R. P.; Joseph, M. Synth. React. Inorg. Met. Org. Chem. 2003 33, 275-281.

[37]. Philip, V.; Suni, V.; Kurup, M. R. P.; Nethaji, M. Polyhedron 2004, 23, 1225-1233.

[38]. El-Sherif, A. A.; Jeragh, B. J. A. J. Spectrochim. Acta A 2007, 68, 877-882.

[39]. West, D. X.; El-Sawaf, A. K.; El-Saied, F. A.; Elbahnsawy, R. M. Transit Metal. Chem. 1998, 23, 565-572.

[40]. West, D. X.; Lockwood, M. A.; Liberta, A. E.; Willett, R. D. Transit. Metal Chem. 1997, 22, 366-371.

[41]. Stefov, V.; Petrusevski, V. M.; Soptrajanov, B. J. Mol. Struct. 1993, 293 97-100.

[42]. Lever, A. B. P. Inorganic Electronic Spectroscopy, 2nd Edition, Elsevier, Amsterdam, 1984

[43]. Nakamoto, K. Infrared and Raman Spectra of Inorganic and Coordination Compounds, Wiley-Interscience, New York, 1986.

[44]. Philip, V.; Suni, V.; Kurup, M. R. P. Polyhedron 2006, 25, 1931-1938.

[45]. Sankaraperumal, A.; Karthikeyan, J.; Shetty, A. N.; Lakshmisundaram, R. Polyhedron 2013, 50, 264-269.

[46]. Suzuki, M.; Kanatomi, H.; Koyama, H.; Murase, I. Bull. Chem. Soc. Japan 1980, 53, 1961-1970.

[47]. Li, Q.; Tang, H.; Li, Y.; Wang, M.; Wang, L.; Xia, C. J. Inorg. Biochem. 2000, 78, 167-178.

[48]. Mukhopadhyay, A.; Padmaja, G.; Pal, S.; Pal, S. Inorg. Chem. Commun. 2003, 6, 381-386.

[49]. M. A. Ali; Hossain, S. M. G.; Majumder, S. M. M. H.; Nazimuddin, M. Tazafder M. T. H. Polyhedron 1987, 6, 1653-1656.

[50]. Leovac, V. M.; Jovanovic, L. S.; Divijakovic, V.; Pevec, A.; Leban, I.; Armbruster, T. Polyhedron 2007, 26, 49-58.

[51]. Ferrari, M. B.; Capacchi, S.; Pelosi, G.; Reffo, G.; Tarasconi, P.; Al-bertini, R.; Pinelli, S.; Helicin, P. L. Inorg. Chim. Acta 1999, 286, 134-141.

[52]. Jayabalakrishnan, C.; Natarjan, K. Synth. React. Inorg. Met. Org. Chem 2001, 31, 983-988.

[53]. Jeeworth, T.; Wah, H. L. K.; Bhowon, M. G.; Ghoorhoo, D.; Babooram, K. Synth. React. Inorg. Met. Org. Chem. 2002, 30, 1023-1038.

[54]. Dharmaraj, N.; Viswanathamurthi, P.; Natarajan, K. Transit. Met. Chem. 2001, 26, 105-112.

[55]. Pal, I.; Basuli, F.; Bhattacharya, S. Chem. Sci. 2002, 114(4), 255-268.

[56]. Anjaneyula, Y.; Rao, R. P. Synth. React. Inorg. Met. Org. Chem. 1986, 16, 257-272.

[57]. Chohan, Z. H.; Arif, M.; Akhtar, M. A.; Supuran, C. T. Bioinorg. Chem. Appl. 2006, Vol. 2006, Article ID 83131.

[58]. Chohan, Z. H.; Scozzafava, A.; Supuran, C. T. J. Enzym. Inhib. Med. Ch 2003, 18(3), 259-263.

[59]. Prasad, K. S.; Kumar, L. S.; Shekar, S. C.; Prasad, M.; Revanasiddappa, H. D. J. Chem. Sci. 2011, 12, 1-10.

[60]. Thangadurai, T. D.; Natarajan, K.; Transit. Metal Chem. 2001, 26(4-5), 500-504.

[61]. Dharmaraj, N.; Viswanathamurthi, P.; Natarajan, K. Transit. Metal Chem. 2001, 26(1-2), 105-109.

[62]. Joseyphus, R.; Nair, M. Mycobiology 2008, 36, 93-98.

[63]. Malhota, L.; Kumar, S.; Dhindsa, K. S. Indian J. Chem. A 1993, 32, $457-$ 459.

[64]. Koch, A. L. Clin. Microbiol. Rev. 2003, 16, 673-678.

[65]. Collins, R. C.; Davis, R. E. Acta Crystallogr. B 1978, 34, 283-285.

[66]. Arjunan, P.; Ramamurthy, V.; Ventakesan, K. Acta Crystallogr. C 1984 40, 556-552.

[67]. Pearson, R. G. J. Org. Chem. 1989, 54, 1423-1427.

[68]. Parr, R. G.; Pearson, R. G. J. Am. Chem. Soc. 1983, 105, 7512-7516.

[69]. Geerlings, P.; De Proft, F.; Langenaeker, W. Chem. Rev. 2003, 103, 1793-1873.

[70]. Parr, R. G. J. Am. Chem. Soc. 1999, 121, 1922-1924.

[71]. Chattaraj, P. K.; Giri, S. J. Phys. Chem. A 2007, 111, 1116-1126. 
[72]. Speie, G.; Csihony, J.; Whalen, A. M.; Pie-pont, C. G. Inorg. Chem. 1996, 35, 3519-3535.

[73]. Sagdinc, S.; Koksoy, B.; Kandemirli, F.; Bayari, S. H. J. Mol. Struct. 2009, 917, 63-70.

[74]. Masoud, M. S.; Ali, A. E.; Shaker, M. A.; Elasala, G. S. Spectrochim. Acta A 2012, 90, 93-108.

[75]. Xia, S. W.; Xu, X.; Sun, Y. L.; Fan, Y. L.; Fan, Y. H.; Bi, C. F.; Zhang, D. M.; Yang, L. R. Chin. J. Struct. Chem. 2006, 25, 200-207.

[76]. Carcelli, M.; Mazza, P.; Pelizzi, C.; Pelizzi, G.; Zani, F. J. Inorg. Biochem. 1995, 57, 43-62. 